\title{
The complete genome sequences of 22 parrot species
}

\section{(Psittaciformes, Aves) [version 1; peer review: 3 approved with}

\section{reservations]}

\author{
Taylor Hains ${ }^{1}$, Kathleen O'Neill², Jafet Velez ${ }^{3}$, Nancy Speed ${ }^{4}$, Susan Clubb4, \\ Taras Oleksyk ${ }^{5}$, Stacy Pirro (D)2
}

\author{
${ }^{1}$ Parrot Conservation, Terra Wildlife Genomics, Washington, DC, 20037, UK \\ 2Biodiversity, Iridian Genomes, Bethesda, MD, 20817, USA \\ ${ }^{3}$ Conservation Program of the Puerto Rican Parrot, U.S. Fish and Wildlife Service, Rio Grande, PR, 00745, USA \\ ${ }^{4}$ Rainforest Clinic for Birds \& Exotics, Hurricane Aviaries Inc, Loxahatchee, FL, 33470, USA \\ ${ }^{5}$ Department of Biological Sciences, Oakland University, Rochester, MI, 48309, USA
}

V1 First published: 12 Nov 2020, 9:1318

https://doi.org/10.12688/f1000research.25560.1

Latest published: 12 Nov 2020, 9:1318

https://doi.org/10.12688/f1000research.25560.1

\section{Abstract}

The parrots (Psittaciformes, Aves) are a group of colorful, intelligent, long-lived birds with a wide range of body sizes and plumage colors and patterns. One third of the parrot species is threatened with extinction due to habitat loss and the pet trade, a larger percentage than any other comparable bird order. We present the complete genome sequences of 22 species of parrots from 14 genera and 3 families: Anodorhynchus hyacinthinus, Ara ararauna, Ara chloropterus, Ara glaucogularis, Ara militaris, Aratinga solstitialis, Aratinga weddellii, Cacatua leadbeateri, Eclectus roratus, Eupsittula pertinax, Guaruba guarouba, Lorius garrulus, Myiopsitta monachus, Nymphicus hollandicus, Pionus senilis, Psittacus erithacus, Psittacus timneh, Psitteuteles goldiei, Pyrrhura frontalis, Pyrrhura griseipectus, Pyrrhura molinae, Pyrrhura perlata. Genomic data can be used to better understand species identity, hybridization, genetic diversity, and identification of animal products possibly derived from endangered species.

\section{Keywords}

Parrots, birds, Psittaciformes, cockatoos, genomes

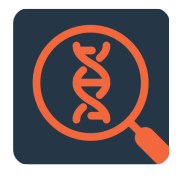

This article is included in the Genomics and Genetics gateway.

\section{Open Peer Review}

$\begin{array}{cccc}\text { Approval Status } & ? ? ? & \\ & 1 & 2 & 3 \\ \text { version 1 } & ? & ? & ? \\ 12 \text { Nov 2020 } & \text { view } & \text { view } & \text { view }\end{array}$

1. Paweł Mackiewicz iD, University of Wrocław, Wrocław, Poland

2. Devon DeRaad ID, Kansas University, Kansas, USA

John McCormack, Occidental College, Los Angeles, USA

3. Roberto Ambrosini (D), University of Milan, via Celoria 26, Italy

Simona Secomandi, University of Milan, via Celoria 26, Italy

Any reports and responses or comments on the article can be found at the end of the article. 
Corresponding author: Stacy Pirro (info@iridiangenomes.org)

Author roles: Hains T: Resources; O'Neill K: Resources; Velez J: Resources; Speed N: Resources; Clubb S: Resources; Oleksyk T:

Resources; Pirro S: Funding Acquisition, Investigation, Methodology, Project Administration, Software

Competing interests: No competing interests were disclosed.

Grant information: This work was supported by Iridian Genomes [IRGEN-9223].

Copyright: @ 2020 Hains T et al. This is an open access article distributed under the terms of the Creative Commons Attribution License, which permits unrestricted use, distribution, and reproduction in any medium, provided the original work is properly cited.

How to cite this article: Hains T, O'Neill K, Velez J et al. The complete genome sequences of 22 parrot species (Psittaciformes, Aves) [version 1; peer review: 3 approved with reservations] F1000Research 2020, 9:1318 https://doi.org/10.12688/f1000research.25560.1

First published: 12 Nov 2020, 9:1318 https://doi.org/10.12688/f1000research.25560.1 


\section{Introduction}

The parrots (Psittaciformes, Aves) are an order of 370 extant species (Clements et al., 2019) characterized by high intelligence (Pepperberg, 2017), diverse plumage colors and patterns (Berg \& Bennett, 2010), and clawed zygodactyl feet (Botelho et al., 2014.) A third of all parrot species are threatened by extinction due to habitat loss and the practice of capturing young birds for the pet trade (Butchart et al., 2004).

Complete genome sequences for parrot species will benefit such diverse fields as biodiversity, evolutionary studies, species hybridization, and research into the development of brain function. Genomic data will also aid in the development of molecular markers to identify products, which may be derived from endangered species (Yang et al., 2018).

\section{Methods}

Samples from 22 parrot species were obtained from molted feathers from pet birds, and blood samples from birds from captive breeding programs (Table 1). Where blood samples were used, they were obtained by a licensed veterinarian coinciding with a standard health check. Animals were handled in a manner consistent with accepted practices (NRC, 2011). In the case of molted feathers, pulp was excised from the shaft of a large tail or primary wing feather prior to extraction.

\section{Table 1. Species sequenced for this study.}

\begin{tabular}{|c|c|c|c|c|c|}
\hline Scientific name & Common name & Accession number & Genome size & $\begin{array}{l}\text { Sample } \\
\text { type }\end{array}$ & Family name \\
\hline $\begin{array}{l}\text { Anodorhynchus } \\
\text { hyacinthinus }\end{array}$ & Hyacinth Macaw & GCA_009936445 & $1,119,461,287$ & feather & Psittacidae \\
\hline Ara ararauna & $\begin{array}{l}\text { Blue-And-Yellow } \\
\text { Macaw }\end{array}$ & GCA_010014805 & $1,128,178,780$ & blood & Psittacidae \\
\hline Ara chloropterus & $\begin{array}{l}\text { Red-And-Green } \\
\text { Macaw }\end{array}$ & GCA_010014725 & $1,117,846,189$ & feather & Psittacidae \\
\hline Ara glaucogularis & Blue-Throated Macaw & GCA_010015425 & $1,135,105,966$ & feather & Psittacidae \\
\hline Ara militaris & Military Macaw & GCA_010015965 & $1,177,230,593$ & feather & Psittacidae \\
\hline Aratinga solstitialis & Sun Parakeet & GCA_009867195 & $1,214,690,015$ & feather & Psittacidae \\
\hline Aratinga weddellii & $\begin{array}{l}\text { Dusky-headed } \\
\text { Parakeet }\end{array}$ & GCA_009867205 & $1,114,053,963$ & blood & Psittacidae \\
\hline Cacatua leadbeateri & $\begin{array}{l}\text { Major Mitchell's } \\
\text { Cockatoo }\end{array}$ & GCA_010015045 & $1,069,984,771$ & feather & Cacatuidae \\
\hline Eclectus roratus & Eclectus Parrot & GCA_011763535 & $1,101,365,900$ & feather & Psittacidae \\
\hline Eupsittula pertinax & $\begin{array}{l}\text { Brown-Throated } \\
\text { Parakeet }\end{array}$ & GCA_011317185 & $1,171,654,275$ & feather & Psittacidae \\
\hline Guaruba guarouba & Golden Parakeet & GCA_011800095 & $1,151,548,123$ & blood & Psittacidae \\
\hline Lorius garrulus & Chattering Lory & GCA_010014925 & $1,091,728,784$ & feather & Psittaculidae \\
\hline Myiopsitta monachus & Monk Parakeet & GCA_013036005 & $1,118,816,385$ & feather & Psittacidae \\
\hline Nymphicus hollandicus & Cockatiel & GCA_009823435 & $1,205,077,083$ & feather & Cacatuidae \\
\hline Pionus senilis & White-Capped Parrot & GCA_011762725 & $1,067,577,099$ & feather & Psittacidae \\
\hline Psittacus erithacus & Grey Parrot & GCA_009867235 & $1,118,034,822$ & blood & Psittacidae \\
\hline Psittacus timneh & Timneh Parrot & GCA_009867315 & $1,103,923,287$ & blood & Psittacidae \\
\hline Psitteuteles goldiei & Goldie's Lorikeet & GCA_010014875 & $1,125,670,205$ & feather & Psittaculidae \\
\hline Pyrrhura frontalis & $\begin{array}{l}\text { Maroon-Bellied } \\
\text { Parakeet }\end{array}$ & GCA_010014865 & $1,112,821,352$ & blood & Psittacidae \\
\hline Pyrrhura griseipectus & $\begin{array}{l}\text { Gray-Breasted } \\
\text { Parakeet }\end{array}$ & GCA_010014965 & $1,129,186,538$ & blood & Psittacidae \\
\hline Pyrrhura molinae & $\begin{array}{l}\text { Green-Cheeked } \\
\text { Parakeet }\end{array}$ & GCA_011763355 & $1,122,251,672$ & blood & Psittacidae \\
\hline Pyrrhura perlata & $\begin{array}{l}\text { Crimson-bellied } \\
\text { Parakeet }\end{array}$ & GCA_011763455 & $1,111,465,322$ & blood & Psittacidae \\
\hline
\end{tabular}


DNA extraction was performed on blood and feather pulp using the Qiagen DNAeasy genomic extraction kit, using the manufacturer's process. A paired-end sequencing library was constructed using the Illumina TruSeq kit, according to the manufacturer's instructions. The library was commercially sequenced at Genewiz (New Jersey, USA) on an Illumina Hi-Seq platform in paired-end, 2 x 150bp format.

The resulting fastq files were trimmed of adapter/primer sequence and low-quality regions with Trimmomatic (v0.33) (Bolger et al., 2014). The trimmed sequence was assembled by SPAdes (v2.5) (Bankevich et al., 2012). This was followed by a finishing step using RagTag (v1.0.0) (Alonge, 2020) to make additional contig joins based on conserved regions in other parrot species: Melopsittacus undulatus (GCA_012275295),
Amazona guildingii (GCA_013399615), Agapornis roseicollis (GCA_002631895), and other species in this study.

\section{Results}

The genome sizes and NCBI Assembly accessions for each species are shown in Table 1.

Genome sizes ranged from $1.07-1.21 \mathrm{G}$ (scaffolded), with no clear delineation between the three represented families (Psittacidae, Psittaculidae, Cacatuidae).

\section{Data availability}

Underlying data

Accession numbers for all genome sequences in GenBank can be found in Table 1 .
Alonge M: Ragtag: Reference-guided genome assembly correction and scaffolding. GitHub Archive. 2020

Publisher Full Text

Bankevich A, Nurk S, Antipov D, et al.: SPAdes: A New Genome Assembly Algorithm and Its Applications to Single-Cell Sequencing. J Comput Biol. 2012; 19(5): 455-477.

PubMed Abstract | Publisher Full Text | Free Full Text

Berg ML, Bennett ATD: The evolution of plumage colouration in parrots: a review. Emu - Austral Ornithology. 2010; 110(1): 10-20.

Publisher Full Text

Bolger AM, Lohse M, Usadel B: Trimmomatic: A flexible trimmer for Illumina

Sequence Data. Bioinformatics. 2014; 30(15): 2114-20.

PubMed Abstract | Publisher Full Text | Free Full Text

Botelho JF, Smith-Paredes D, Nuñez-Leon D, et al: The developmental origin of zygodactyl feet and its possible loss in the evolution of Passeriformes.

Proc Biol Sci. 2014; 281(1788): 20140765.

PubMed Abstract | Publisher Full Text | Free Full Text
Butchart SH, Stattersfield AJ, Bennun LA, et al.: Measuring global trends in the status of biodiversity: red list indices for birds. PLOS Biol. 2004; 2(12): e383.

PubMed Abstract | Publisher Full Text | Free Full Text

Clements JF, Schulenberg TS, Iliff MJ, et al.: The eBird/Clements Checklist of Birds of the World: v2019. 2019.

Reference Source

National Research Council: Guide for the Care and Use of Laboratory Animals. Eighth edition, 2011.

Reference Source

Pepperberg IM: "Birdbrains" should not be ignored in studying the evolution of $\boldsymbol{g}$. Behav Brain Sci. 2017; 40: e216.

PubMed Abstract | Publisher Full Text

Yang $F$, Ding $F$, Chen $\mathrm{H}$, et al: DNA barcoding for the identification and authentication of animal species in traditional medicine. Evid Based

Complement Alternat Med. 2018; 2018: 5160254.

PubMed Abstract | Publisher Full Text | Free Full Text 


\section{Open Peer Review}

\section{Current Peer Review Status: ? ? ?}

\section{Version 1}

Reviewer Report 26 October 2021

https://doi.org/10.5256/f1000research.28208.r96540

(C) 2021 Ambrosini R et al. This is an open access peer review report distributed under the terms of the Creative Commons Attribution License, which permits unrestricted use, distribution, and reproduction in any medium, provided the original work is properly cited.

\section{Roberto Ambrosini}

Department of Environmental Science and Policy, University of Milan, via Celoria 26, Milano, 20133, Italy

\section{Simona Secomandi}

Department of Biosciences, University of Milan, via Celoria 26, Milano, 20133, Italy

The paper by Hains and co-authors provides NCBI accession numbers for 22 scaffold-level parrot genome assemblies. These data have the potential to add a consistent number of parrot genomes to the current literature and are therefore very valuable. However, there are a series of points that we think can be improved.

Despite this work being published as a data note and no detailed results are therefore expected, the data description is too brief, in our opinion.

More details on the quality and contiguity of the assemblies should be provided, at least the N50 or the NG50 statistics, the number of scaffolds, and some QV statistics, like those produced by Merqury (Rhie et al. 2020) ${ }^{1}$.

The title also claims that the genomes are complete, but the paper does not provide any metrics about it. Usually, short Illumina reads can not resolve the repetitive regions of the genome. We understand that the authors probably could not reach the chromosome-level due to technical limitations (e.g. Hi-C data to join the scaffolds seem not available), still, we suggest providing some measure of the completeness of their assemblies both at structural ( $\mathrm{k}$-mer completeness form Merqury) and functional (from Busco analysis (Manni et al. 2021) ${ }^{2}$ ) level. For similar reasons, we think that the title should be changed by replacing the term "complete" with "scaffold-level" as the latter describes the quality of the described genomes more accurately.

We also suggest adding more information about how samples were acquired (permissions and ethic statements). I am also concerned by the fact that the parrots can hybridize in captivity, so detailed information about the (potential) hybrid status of each individual should be provided. 
We hope our suggestions can help the authors to further improve their paper.

\section{References}

1. Rhie A, Walenz B, Koren S, Phillippy A: Merqury: reference-free quality, completeness, and phasing assessment for genome assemblies. Genome Biology. 2020; 21 (1). Publisher Full Text 2. Manni M, Berkeley MR, Seppey M, Simão FA, et al.: BUSCO Update: Novel and Streamlined Workflows along with Broader and Deeper Phylogenetic Coverage for Scoring of Eukaryotic, Prokaryotic, and Viral Genomes.Mol Biol Evol. 2021; 38 (10): 4647-4654 PubMed Abstract |

Publisher Full Text

Is the rationale for creating the dataset(s) clearly described?

Partly

Are the protocols appropriate and is the work technically sound? Partly

Are sufficient details of methods and materials provided to allow replication by others? Yes

Are the datasets clearly presented in a useable and accessible format? Partly

Competing Interests: No competing interests were disclosed.

Reviewer Expertise: Bird ecology (RA) and genomics (SS).

We confirm that we have read this submission and believe that we have an appropriate level of expertise to confirm that it is of an acceptable scientific standard, however we have significant reservations, as outlined above.

Reviewer Report 08 April 2021

https://doi.org/10.5256/f1000research.28208.r82331

(C) 2021 McCormack J et al. This is an open access peer review report distributed under the terms of the Creative Commons Attribution License, which permits unrestricted use, distribution, and reproduction in any medium, provided the original work is properly cited.

Devon DeRaad

Department of Ecology \& Evolutionary Biology, Kansas University, Kansas, USA John McCormack

Moore Laboratory of Zoology, Occidental College, Los Angeles, CA, USA

These are potentially very valuable data for avian genomics, as they increase the number of parrot genomes many times. These data will provide valuable resources for evolution and conservation genomics study. 
This study has a few limitations, detailed below:

1. The biggest limitation is the inability to link the genomic information with certainty to a taxonomic name because of the lack of a voucher specimen and uncertainty about the possible hybrid status of pet parrots. The samples come from either pet birds or birds in captive breeding programs. While birds in captive breeding programs are more likely to be genetically pure, pet parrots could come from anywhere (even the illegal pet trade). Parrot species are known to hybridize in introduced habitats, in the wild, and in captivity-and can even produce viable offspring between genera (Hernandez-Brito et al. 2021 in Ibis ${ }^{1}$ ). More details on provenance might alleviate some concerns, but it will be hard to get away from some uncertainty about whether these genomes are accurate representations of their taxonomic identifiers.

2. The genomes are not complete, since the assemblies come from Illumina short reads and likely do not cover certain, more difficult regions of the genome. Information on depth of sequencing and contiguity (e.g., N50) is available on NCBI, but should also appear in the table to allow readers to assess genome quality more directly.

3. The introduction would be enriched by a little more information on the rationale for the study. Specifically, what is currently missing from parrots studies that these genomes could provide? Describe existing genomic resources and then narrow to a knowledge gap that the authors hope to fill with these genomes. Was there a rationale for the specific species chosen?

4. Likewise, the Discussion would benefit from more elaboration on the broad utility of these datasets, e.g., mapping whole genome re-sequence data or reduced representation sequence data for population genetics studies, etc. Specifically, which uses might not be diminished by some uncertainty surrounding taxonomic assignment?

\section{References}

1. Hernández-Brito D, Tella J, Carrete M, Blanco G: Successful hybridization between noncongeneric parrots in a small introduced population. Ibis. 2021. Publisher Full Text

\section{Is the rationale for creating the dataset(s) clearly described?}

Partly

Are the protocols appropriate and is the work technically sound? Partly

Are sufficient details of methods and materials provided to allow replication by others? No

Are the datasets clearly presented in a useable and accessible format? Yes

Competing Interests: No competing interests were disclosed. 
Reviewer Expertise: Phylogenetics, genomics, birds

We confirm that we have read this submission and believe that we have an appropriate level of expertise to confirm that it is of an acceptable scientific standard, however we have significant reservations, as outlined above.

Reviewer Report 19 February 2021

https://doi.org/10.5256/f1000research.28208.r77387

(C) 2021 Mackiewicz P. This is an open access peer review report distributed under the terms of the Creative Commons Attribution License, which permits unrestricted use, distribution, and reproduction in any medium, provided the original work is properly cited.

\section{Paweł Mackiewicz}

Department of Genomics, Faculty of Biotechnology, University of Wrocław, Wrocław, Poland

The manuscript was submitted to the section Data Note. It presents very briefly the description of nuclear genomes from 22 parrot species. Although the importance of these genomes is crucial for various analyses, the presentation should be improved.

The title indicates that the genomes are complete, whereas the obtained sequences are not assembled and are still organized in scaffolds. Therefore, the title should be changed and the authors should describe in more detail the data set including information about incompleteness and gaps in the sequences. The limitations of the datasets should necessary be presented.

The authors should state which type of analyses can be performed on such incomplete data set and which further steps should be performed to assembly the sequences.

Could you answer for the following questions:

Which problems prevented the obtaining the complete genomes? Are the authors going to assembly and study these genomes in the future?

Moreover, the authors should present in detail sources for each studied sample, e.g. zoo, natural environment with detailed localization, individual breeders, reservation etc. It is essential. Describe in detail the captive breeding programs in the context of the samples, which you mentioned. Ethics policies should be also included. Were the samples obtained and transferred according to the species protection law? It should be clearly stated.

Although my review may seem harsh, actually I think that the obtained genomic sequences are valuable for various studies and the data set is interesting for scientific community. I am very willing to accept the manuscript after the inclusion of information and explanations that I mentioned in my review.

Is the rationale for creating the dataset(s) clearly described? Partly

Are the protocols appropriate and is the work technically sound? Partly

Are sufficient details of methods and materials provided to allow replication by others? 


\section{Partly}

Are the datasets clearly presented in a useable and accessible format? Partly

Competing Interests: No competing interests were disclosed.

Reviewer Expertise: bioinformatics, genomics, phylogenetics, molecular evolution

I confirm that I have read this submission and believe that I have an appropriate level of expertise to confirm that it is of an acceptable scientific standard, however I have significant reservations, as outlined above.

The benefits of publishing with F1000Research:

- Your article is published within days, with no editorial bias

- You can publish traditional articles, null/negative results, case reports, data notes and more

- The peer review process is transparent and collaborative

- Your article is indexed in PubMed after passing peer review

- Dedicated customer support at every stage

For pre-submission enquiries, contact research@f1000.com

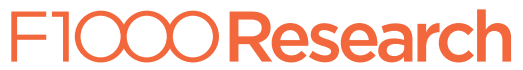

